American Research Journal of Humanities and Social Sciences

(ARJHSS)

ISSN (Online) : 2378-7031

Volume 2016, 1- 4 pages

AMERICAN RESEARCH JOURNALS

An Academic Publishing House

DOI: 10.21694/2378-7031.16013

Research Article

Open Access

\title{
Need and Importance of Female Education
}

\author{
Ruhee Rashid ${ }^{1}$, Dr. Mamta Kumari ${ }^{2}$ \\ ${ }^{1}$ Research Scholar Department of Education OPJS University Churu Rajasthan (India) \\ ${ }^{2}$ Professor Head of Department of Education OPJS University Churu Rajasthan (India) \\ dmbhat5979@gmail.com
}

Abstract: Education is very important need for every human being. Female education is more important than male education because if you educate one male you educate only one person but if you educate a girl you educate whole family. When girls are not educated everyone suffers. Female education is as important three basic needs that is food, cloth and shelters. In this study we discuss the need and importance of female education in district Kulgam of Jammu and Kashmir. During this research sample of 800 males and females are selected from different education institutions and different Tehsil of district Kulgam as 100 primary, 100 middle, 100 high and 100 higher secondary school students, 400 male and female using stratified random sampling technique.

Keywords: Female education, schools, need and importance, Kulgam.

\section{INTRODUCTION}

Education is very important for each and every human being. By education we can differentiate between right and wrong, good and bad, animals and human beings. Only education tells us that how a person can live in a society, it humanize humanity. So education is very important for everyone, both for women and men. In ancient time, females did not receive any type of education. Females were not allowed to come out of the four walls of their houses. Only works at their homes were their education. In 21th century there is no difference between male and female. In this century female have the same respect as male. In every sphere they help each other. So it is important to be given education to both male and female. Female covers half of the total population of the world. So, female must not be left uneducated and in darkness. A female of a house has a much capacity to do work than a man. Their duties do not end in feeding and cooking [1]. Female have much important need of education than male. Male and female are like the two wings of a bird, so it is thought that both must be equally educated. Most of the people think that female do not need education and they do not want to educate their females. They think that female take care of everyone except themselves. Female to stay at home, clean their house and take care of their children and be the self-denying wife and mother. Most of the people think that female is all about getting married, having children. People do not understand that the education is very important not only for men but for women as whole family. This is due to the fact that women are the mothers of the future generation. Future generations will remain uneducated if women are uneducated. In daily life various problems are faced by female if not solved then the same problems will be conveyed to male for solution. An educated female can solve all the problems of their homes. It is true that education of men is only for one person but education of female is the education of whole family. Whole family can be educated by an educated woman and such educated family can makes society better. It is not possible to imagine a good society without the education of female. Women cannot manage whole family without education. Male and female are like the two sides of a coin. One cannot exist without other. Educated female cannot make only an educated family but can also be helpful in overcome many social problem such as unemployment and dowry etc [2]. 
A female has three fundamental duties in her life. The first duty of female is to be a good daughter, second duty of female is to be a good wife and the third duty is to be a good mother. An educated woman is the first teacher of her children. It is education with which women can know their rights.

The women have reached outer space of the universe. Now day females are advanced in any field sports, science, social work or business due to education. It is education by which a strong building of human being can be made. Any human lacks education he will lacks of making his life, his survival or lacks of growing the chance in life. Various surveys proved that India has maximum youth population and is at the top of countries. This is due to the lack awareness about need of female education. However, the literacy rate of India is very low in comparison to other developing countries and female education chart in India becomes worst [3].

The female education is not given much importance in various parts of Jammu and Kashmir and few of these reasons are early child marriage, dowry, Parda system for female, caste system, myths about education. Most of the people in the rural area think that they should not waste money on her education but save money for her dowry. In these areas girls are married at very early age which makes her interested towards the domestic works. In many places the caste system is so strong the girls of the high caste are studying while the girls of lower caste are not allowed to go to the schools. Some orthodox persons do not allow their daughters to go school because they have no knowledge about need and importance of female education.

With the help of education the female understand what is good and what is bad, what is wrong and what is right. It is only educated female that enlightened or draws their family from darkness to light [4].

In modern times women education can only be gained through the attainment of adequate facilities and functional education to the women. The development is not possible without an efficient, effective education for all male and female education which is related to its daily needs, objectives and goals and it is difficult for such a nation to stand on its own. The quality based education is that type of education with which we can achieve self realization and all that are needed for overall development of the nation [5].

\section{OBJECTIVE OF THIS STUDY}

In this study the main objective are to find out the need and importance of educated female in educational institutions, society, family and health departments of district Kulgam.

\section{ReSEARCH MeTHOdology}

The need and importance of female education in schools, society, and family and health departments are identified by using the tools such as a questionnaire and an interview schedule. This study followed by the procedure of descriptive research, in which importance of female education in Kulgam was thoroughly analyzed. The investigator also conducted discussion with some experts to gather relevant information about the need and importance of women education in Jammu Kashmir and Kulgam.

\section{RESEARCH QUESTIONS}

1. How much need of female education in schools?

2. How much important of female education in society?

3. How much important of female education in family?

4. Is education of female is the education for all?

5. How much important of female education in health department? 
6. How much it is true that educated mother mould the behavior of whole family?

Population and sample

All population samples belong to higher secondary schools and different Tehsils of district Kulgam.

\section{RESULTS AND DISCUSSION}

The results and discussion of this study are given below:

The need and importance of female education in schools, society, and family and health departments are identified by using the tools such as a questionnaire and an interview schedule. This study followed by the procedure of descriptive research, in which importance of female education in Kulgam was thoroughly analyzed. The investigator also conducted discussion with some experts to gather relevant information about the need and importance of women education in Jammu Kashmir and Kulgam. In this study we have taken all the population samples belong to secondary and higher secondary schools and different Tehsils of district Kulgam. 800 respondents of different schools in different Tehsils are selected for this study. 200 respondents $\left(9^{\text {th }} \& 10^{\text {th }}\right.$ class) belongs secondary schools, 200 respondents $\left(11^{\text {th }} \& 12^{\text {th }}\right.$ class) belongs to higher secondary schools in district Kulgam, 400 respondents from four Tehsils, 100 respondents from each Tehsil.

Table 1

\begin{tabular}{|l|l|l|}
\hline Respondents & No. of responses & Percentage \\
\hline $9^{\text {th }}$ class (students) & 65 & $65 \%$ \\
\hline $10^{\text {th }}$ class l(students) & 68 & $68 \%$ \\
\hline $11^{\text {th }}$ class (students) & 73 & $73 \%$ \\
\hline $12^{\text {th }}$ class (students) & 81 & $81 \%$ \\
\hline Tehsil Yaripora(general public) & 85 & $85 \%$ \\
\hline Tehsil Frisal(general public) & 68 & $68 \%$ \\
\hline Tehsil Devsar(general public) & 72 & $72 \%$ \\
\hline Tehsil Kulgam(general public) & 88 & $88 \%$ \\
\hline
\end{tabular}

The above table shows the respondents responses from different school students and general public for the need of female education in schools.

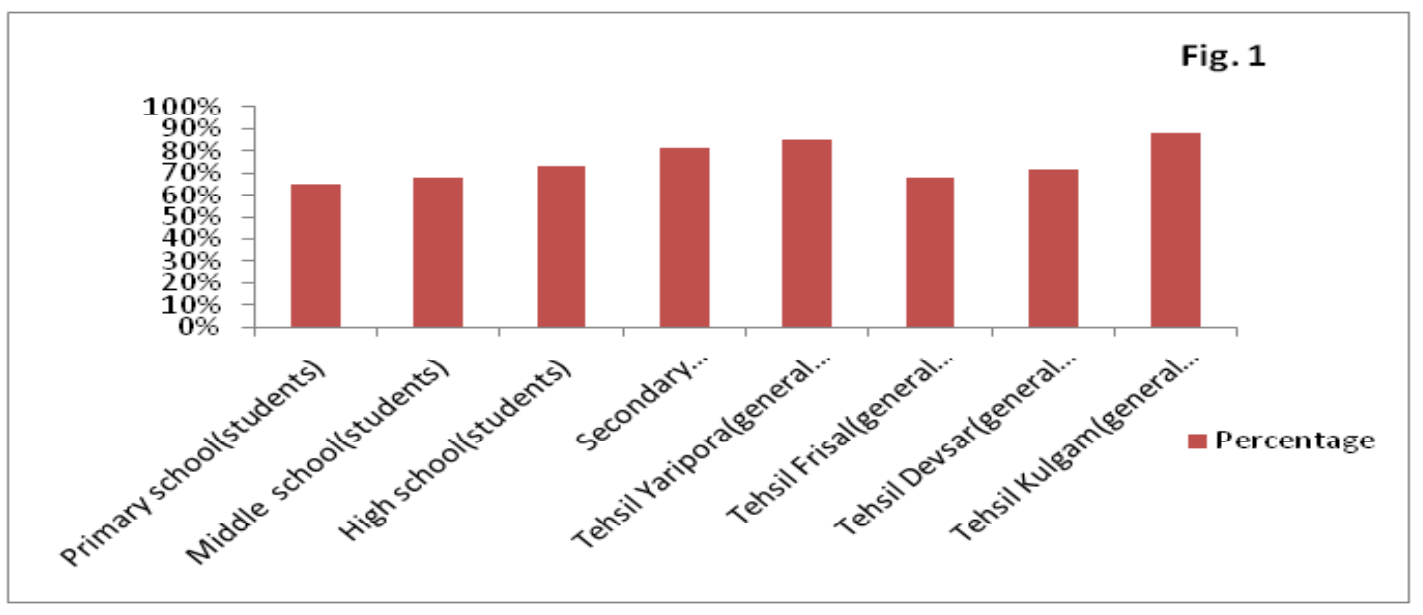

Volume 2016 
American Research Journal of Humanities and Social Sciences (ARJHSS)

The above fig. represents need and importance of female education in schools.

Table 2

\begin{tabular}{|l|l|l|}
\hline Respondents & No. of responses & Percentage \\
\hline $9^{\text {th }}$ class (students) & 71 & $71 \%$ \\
\hline $10^{\text {th }}$ class (students) & 73 & $73 \%$ \\
\hline $11^{\text {th }}$ class (students) & 76 & $76 \%$ \\
\hline $12^{\text {th }}$ class (students) & 78 & $78 \%$ \\
\hline Tehsil Yaripora(general public) & 77 & $77 \%$ \\
\hline Tehsil Frisal(general public) & 70 & $70 \%$ \\
\hline Tehsil Devsar(general public) & 75 & $75 \%$ \\
\hline Tehsil Kulgam(general public) & 83 & $83 \%$ \\
\hline
\end{tabular}

The above table shows the respondents responses from different school students and general public for the importance of female education in society.

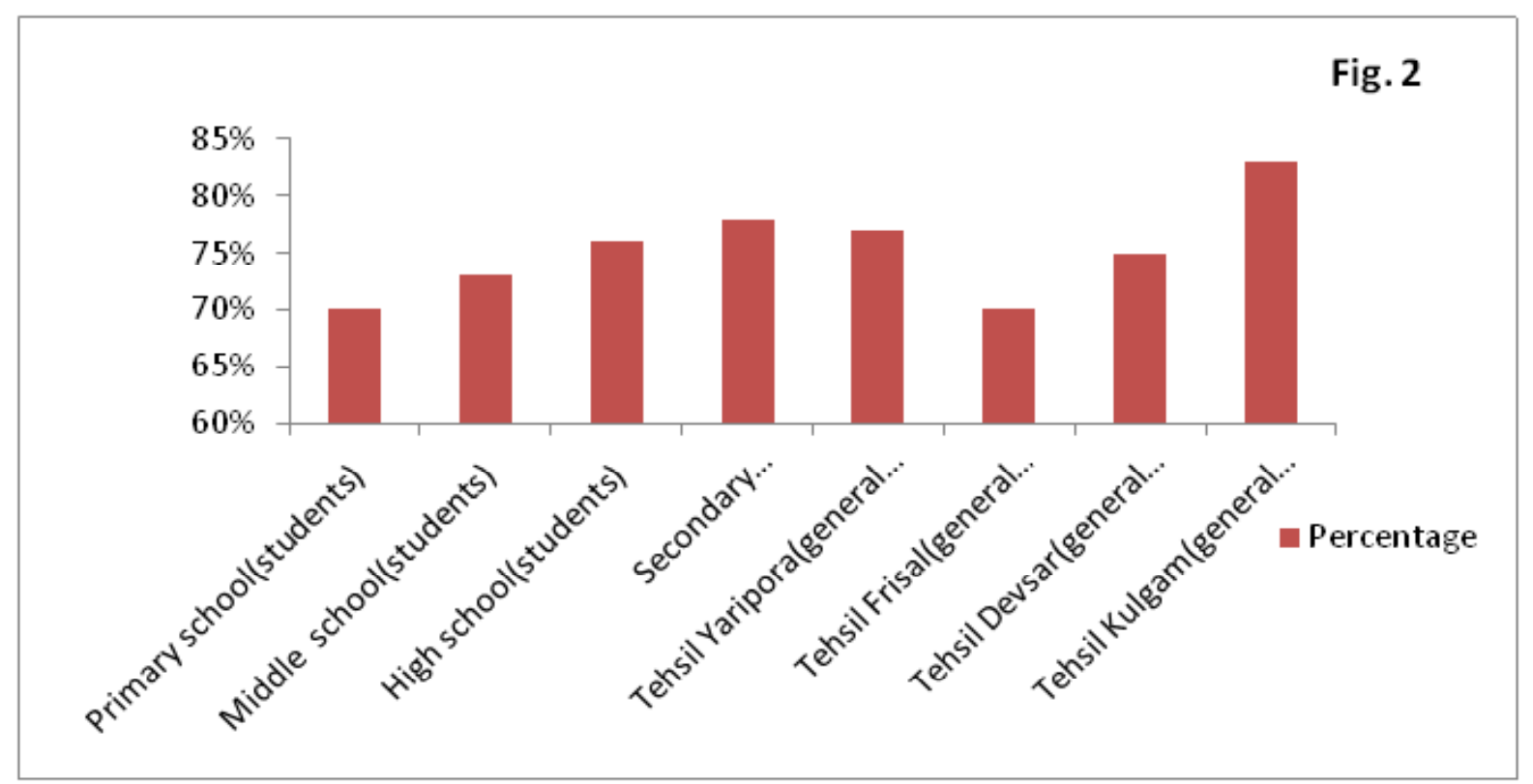

The above fig. represents need and importance of female education in society.

Table 3

\begin{tabular}{|l|l|l|}
\hline Respondents & No. of responses & Percentage \\
\hline $9^{\text {th }}$ class (students) & 66 & $66 \%$ \\
\hline $10^{\text {th }}$ class 1 (students) & 70 & $70 \%$ \\
\hline $11^{\text {th }}$ class (students) & 77 & $77 \%$ \\
\hline
\end{tabular}


American Research Journal of Humanities and Social Sciences (ARJHSS)

\begin{tabular}{|l|l|l|}
\hline $12^{\text {th }}$ class (students) & 79 & $79 \%$ \\
\hline Tehsil Yaripora(general public) & 88 & $88 \%$ \\
\hline Tehsil Frisal(general public) & 78 & $78 \%$ \\
\hline Tehsil Devsar(general public) & 79 & $79 \%$ \\
\hline Tehsil Kulgam(general public) & 95 & $95 \%$ \\
\hline
\end{tabular}

The above table shows the respondents responses from different school students and general public for the importance of educated female in family.

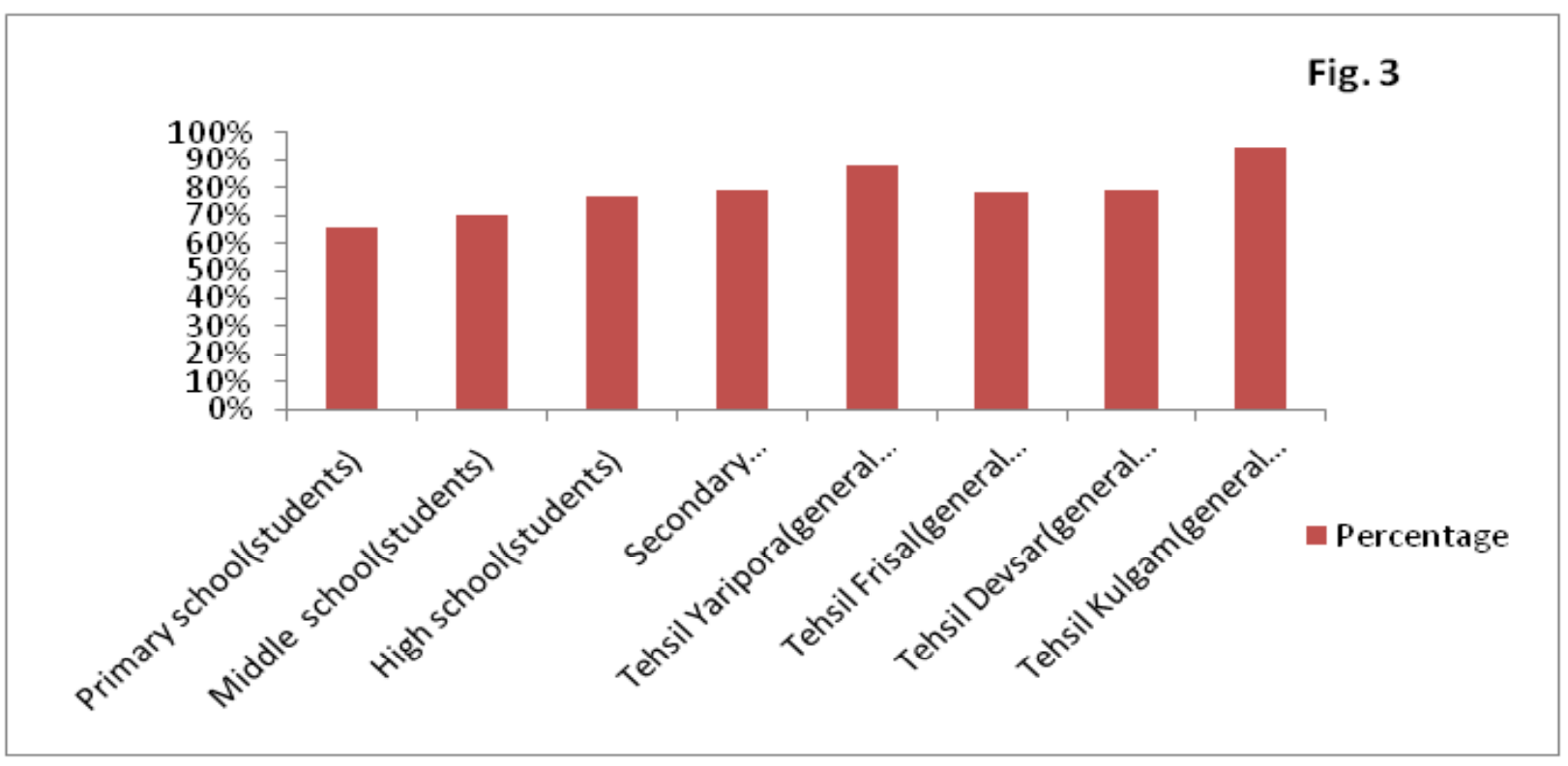

The above fig. represents need of educated female in family

Table 4

\begin{tabular}{|l|l|l|}
\hline Respondents & No. of responses & Percentage \\
\hline $9^{\text {th }}$ class (students) & 60 & $60 \%$ \\
\hline $10^{\text {th }}$ class l(students) & 68 & $68 \%$ \\
\hline $11^{\text {th }}$ class (students) & 74 & $74 \%$ \\
\hline $12^{\text {th }}$ class (students) & 80 & $80 \%$ \\
\hline Tehsil Yaripora(general public) & 87 & $87 \%$ \\
\hline Tehsil Frisal(general public) & 80 & $80 \%$ \\
\hline Tehsil Devsar(general public) & 81 & $81 \%$ \\
\hline Tehsil Kulgam(general public) & 92 & $92 \%$ \\
\hline
\end{tabular}

The above table shows the respondents responses from different school students and general public for the 
education of female is the education for all.

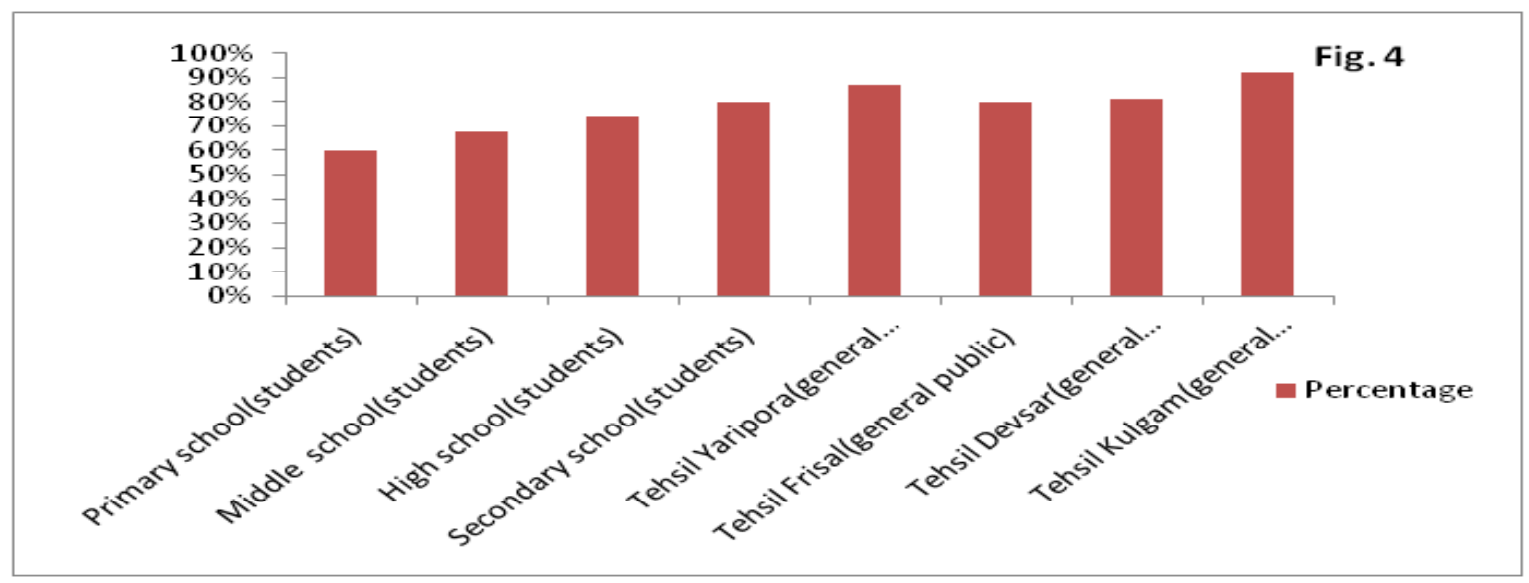

The above fig. represents education of female is the education for all.

Table 5

\begin{tabular}{|l|l|l|}
\hline Respondents & No. of responses & Percentage \\
\hline $9^{\text {th }}$ class (students) & 55 & $55 \%$ \\
\hline $10^{\text {th }}$ class l(students) & 65 & $65 \%$ \\
\hline $11^{\text {th }}$ class (students) & 70 & $70 \%$ \\
\hline $12^{\text {th }}$ class (students) & 81 & $81 \%$ \\
\hline Tehsil Yaripora(general public) & 84 & $84 \%$ \\
\hline Tehsil Frisal(general public) & 82 & $82 \%$ \\
\hline Tehsil Devsar(general public) & 83 & $83 \%$ \\
\hline Tehsil Kulgam(general public) & 94 & $94 \%$ \\
\hline
\end{tabular}

The above table shows the respondents responses from different school students and general public for the importance of female education in health department.

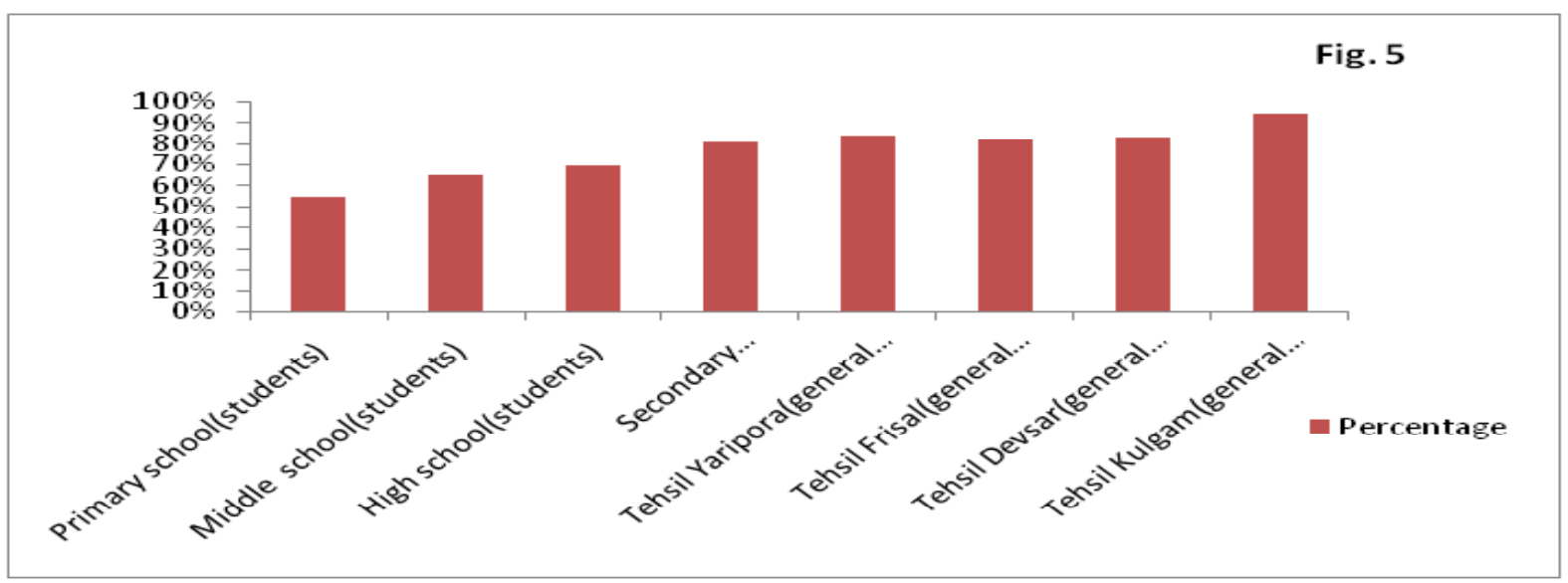


Fig. 6.8

The above fig. represents need of educated female in health department

Table 6

\begin{tabular}{|l|l|l|}
\hline Respondents & No. of responses & Percentage \\
\hline $9^{\text {th }}$ class (students) & 67 & $67 \%$ \\
\hline $10^{\text {th }}$ class l(students) & 70 & $70 \%$ \\
\hline $11^{\text {th }}$ class (students) & 76 & $76 \%$ \\
\hline $12^{\text {th }}$ class (students) & 82 & $82 \%$ \\
\hline Tehsil Yaripora(general public) & 89 & $89 \%$ \\
\hline Tehsil Frisal(general public) & 84 & $84 \%$ \\
\hline Tehsil Devsar(general public) & 83 & $83 \%$ \\
\hline Tehsil Kulgam(general public) & 96 & $96 \%$ \\
\hline
\end{tabular}

The above table shows the respondents responses from different school students and general public for the importance of education of mother that mould the behavior of whole family.

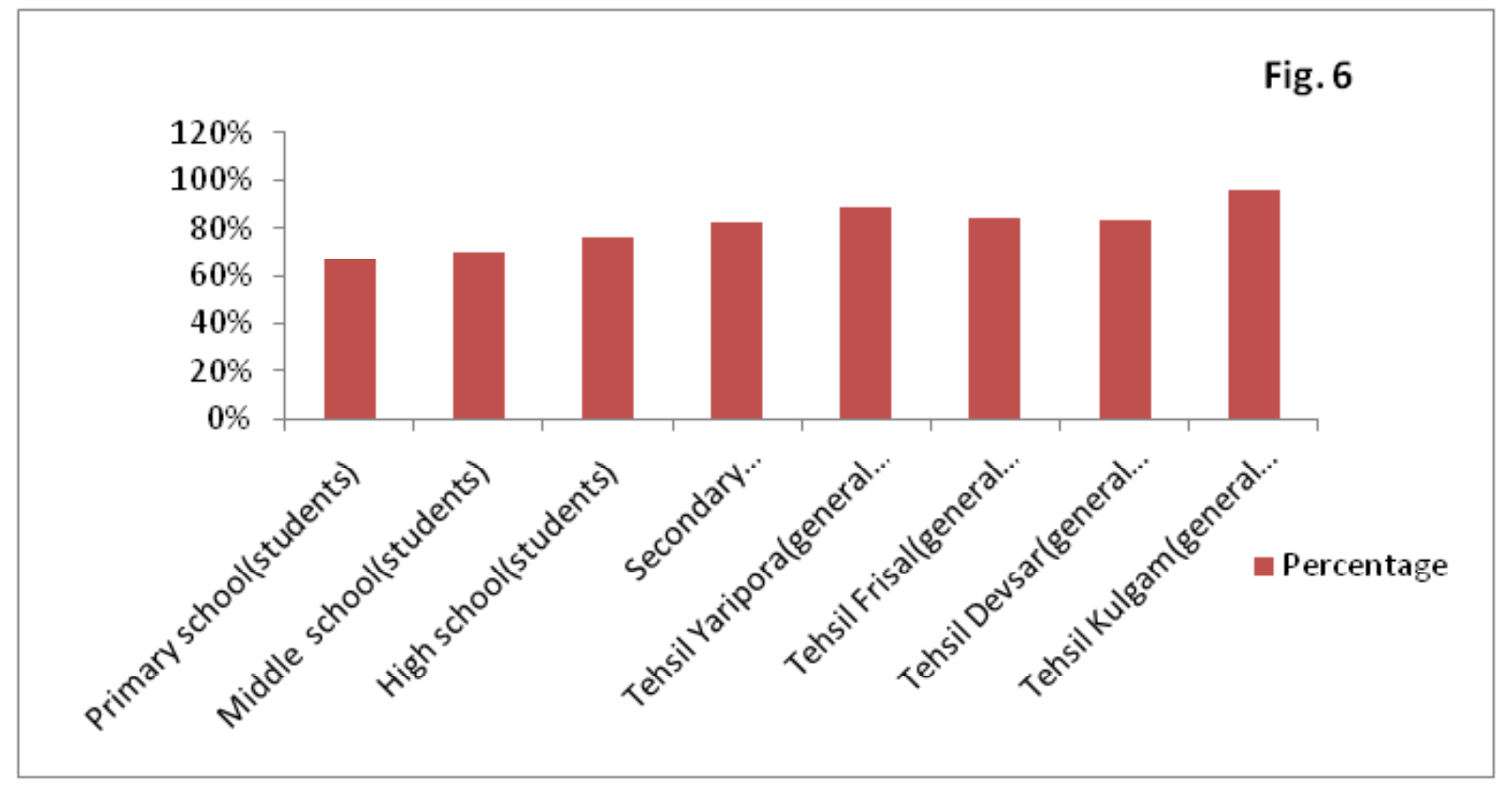

The above fig. represents the importance of educated mother that mould the behavior of whole family.

\section{RESUlts AND Discussion}

The need and importance of female education in schools, society, family and health departments are identified by using the tools such as a questionnaire and an interview schedule by taking 800 respondents, 200 belongs to secondary schools , 200 belongs to higher secondary schools, 400 from four Tehsils as general public. In table 1, when the respondents were asked about the need of female education in schools, the highest $88 \%$ respondents 
from Tehsil Kulgam said that female education is very important in schools for improvement of girl's education followed by Tehsil Yaripora $85 \%$ while the lowest $65 \%$ respondents from $9^{\text {th }}$ class said for the importance of female education in schools. In table 2, when the respondents were asked about the need of female education in society, the highest $83 \%$ respondents from Tehsil Kulgam said that female education is very important for improvement of society while the lowest $70 \%$ respondents from Tehsil Frisal said for the importance of female education in society. In table 3, when the respondents were asked about the need of educated female in family, the highest $95 \%$ respondents from Tehsil Kulgam said that female education is most important part of family while the lowest $66 \%$ respondents from $9^{\text {th }}$ class said for the importance of female education in family. In table 4, when the respondents were asked about the education of female is the education for all, the highest $92 \%$ respondents from Tehsil Kulgam said that education of female is the education for all while the lowest $60 \%$ respondents from $9^{\text {th }}$ class said for the education of female is the education for all. In table 5 , when the respondents were asked about the importance of female education in health department, the highest $94 \%$ respondents from Tehsil Kulgam said that education of female is very important in health department while the lowest $55 \%$ respondents from $9^{\text {th }}$ class said for the importance of female education in health department.

In table 6, when the respondents were asked about the importance of education of mother that mould the behavior of whole family., the highest $96 \%$ respondents from Tehsil Kulgam said that education of mother changes the behavior of whole family while the lowest $67 \%$ respondents from $9^{\text {th }}$ class said for the importance of educated mother that changes the behavior of whole family.

\section{CONCLUSION}

Education is the most powerful path to lift people from poverty to rich life. Female education is very important tool that brings society into prosperous. It is education that reduces the gap of inequalities between male and female within the family.

It is found that education of female is very important in all fields of life. Primary school students have give low responses as compared to middle, high and higher secondary school students. This is due to the fact that primary school students do not know the need and importance of female education, but high and higher secondary school students know very well the importance of female education in all the fields. Because of modernity educational awareness programs in Tehsil Kulgam have know the value, need and importance of female education. Tehsil Yaripora is also known for good educational background, so the people of this Tehsil know very well about the value, need and importance of female education.

It is also observed from this study that other Tehsils like Devsar and Frisal do not know very well as compared to Kulgam and Yaripora.

If females are encouraged at all stages, if Jammu \& Kashmir government should establish separate schools, colleges and universities. Due to this girl education can be enlarged or vast. Government should give more schemes for female education especially from Below Poverty Line (BPL), Scheduled Tribe (ST), Social Cast (SC) and Other Backward Class (OBC). Also free books, free uniforms, special scholarships, lodging and boarding etc. should be provided. 
American Research Journal of Humanities and Social Sciences (ARJHSS)

\section{REFERENCES}

[1] Gupta, N.L. (2003), “Women's Education Through Ages,” Concept Publications Co, New Delhi.

[2] Rao, R.K. (2001), “Women and Education,” Kalpaz Publications, Delhi.

[3] Agarwal S.P. (2001), "Women's Education in India Present Status, Perspective, Plan, Statistical Indicators with Global View," Concept Publications Co, New Delhi. Vol. 3, No.5

[4] Agbakwuru, C. (2002), "The role of primary education in the promotion of national integration and cohesion," Knowledge Review, Vol. 1, No. 2, pp. 15-23.

[5] Esere, M. O. (2001), "Women empowerment and its challenges to gender counseling", Journal of Counselling and Human Development, Vol. 1, No.1, pp. 16-31.

Citation: Ruhee Rashid, Dr. Mamta Kumari, “Need and Importance of Female Education ". American Research Journal of Humanities and Social Sciences, Volume 2016; pp:1-9

Copyright (c) 2016 Ruhee Rashid, Dr. Mamta Kumari, This is an open access article distributed under the Creative Commons Attribution License, which permits unrestricted use, distribution, and reproduction in any medium, provided the original work is properly cited. 